Yüzüncü Yil Üniversitesi
Tarim Bilimleri Dergisi

Araştırma Makalesi (Research Article)

\title{
Hatay’ın Farklı İlçelerinde Yetiştirilen Biber Köy Popülasyonlarında Bitki ve Meyve Özellikleri $^{* * *}$
}

\author{
Gonca ÖNTÜRK ${ }^{1}$, Sebahattin ÇÜRÜK ${ }^{* 2}$ \\ ${ }^{1}$ Hatay Mustafa Kemal Üniversitesi, Fen Bilimleri Enstitüsü, Bahçe Bitkileri ABD, 31060, Hatay, Türkiye \\ ${ }^{2}$ Hatay Mustafa Kemal Üniversitesi, Ziraat Fakültesi, Bahçe Bitkileri Bölümü, 31060, Hatay, Türkiye \\ *Sorumlu yazar e-posta: scuruk@mku.edu.tr
}

\section{Makale Bilgileri}

Geliș: 28.10 .2019

Kabul: 02.12.2019

Online Yayınlanma 31.12.2019

DOI: $10.29133 /$ yyutbd.639261

\section{Anahtar kelimeler}

Capsicum annuum,

Dihidrokapsaisin,

Hatay biberi popülasyonları,

Kapsaisin,

Karakterizasyon.
Öz: Araştırmanın amacı, Hatay biberi (Capsicum annuum L.) köy popülasyonlarında bitki, çiçek ve meyve özellikleri belirlenerek mevcut varyasyonun ortaya çıkarılmasıdır. Çalışmada Hatay'da 16 mahallede çiftçiler tarafından yetiştirilen biber popülasyonlarında bitki, çiçek ve meyve özellikleri incelenmiştir. İncelenen popülasyonlarda bitki büyüme modeli, gövde ve yaprak tüylülüğü, gövde rengi, gövde şekli, yaprak rengi ve şekli, koltuktaki çiçek sayısı, taç yaprak rengi, meyve sapı ile çanak yaprağın birleştiği yerde boğum oluşumu ve meyvede kopma tabakası bakımından değişim olmadığı belirlenmiştir. İncelenen diğer bitki ve meyve özellikleri açısından ise popülasyonlarda varyasyon bulunduğu tespit edilmiştir. Çalışma sonucunda Hatay biberi popülasyonlarının, aralarında benzerlik ve farklılık olmakla birlikte genel olarak Arsuz, Antakya-Yayladağı-Altınözü ve Samandağ olmak üzere üç gruba ayrılabileceği ortaya çıkmaktadır. Arsuz grubu popülasyonlarında genel olarak meyve şekli uzun, çiçek ucu şekli ağırlıklı olarak sivri, meyve az acı olarak belirlenmiştir. Antakya-Yayladağ1-Altınözü grubu; meyve şekli genelde uzun olmakla birlikte konik ve tombul meyveleri bulunan, çiçek ucu şeklinin kubbe, sivri ve çukur, suda çözünür kuru madde içeriği diğer gruplara göre genel olarak daha yüksek ve acılığın çok düşük olduğu popülasyonlar bulunmakla birlikte Arsuz grubuna göre daha acı meyvelere sahip olan bir gruptur. Samandağ biberinde ise varyasyonun diğer gruplardan düşük, genel olarak meyve şeklinin uzun, çiçek ucu şeklinin sivri ve acılığın diğer gruplara kıyasla oldukça yüksek olduğu belirlenmiştir.

\section{Plant and Fruit Characterization in Local Pepper Populations Grown in Different Districts of Hatay}

\section{Article Info}

Received: 28.10.2019

Accepted: 02.12.2019

Online Published 31.12.2019

DOI: 10.29133/yyutbd.639261

\section{Keywords}

Capsicum annuum, Dihydrocapsaicin,

Hatay pepper populations, Capsaicin,

Characterization.
Abstract: The aim of the research is to reveal the variation by determining of plants, flowers and fruits characteristics of Hatay local pepper (Capsicum annuum L.) populations. In the study, the characteristics of plants, flowers and fruits were examined in pepper populations grown by farmers in 16 locations in Hatay. It was determined that there was no variation in the populations examined with respect to plant growth habit, stem and leaf pubescence, stem color, stem shape, leaf color and shape, number of flowers per axil, corolla color, calyx annular constriction and fruit persistence. However, in terms of other plant and fruit characteristics examined, variation was found in the populations. As a result of the study, Hatay pepper populations can be divided into three groups as Arsuz, AntakyaYayladağı-Altınözü and Samandağ in general although there are similarities and differences between the groups. In the Arsuz group populations, generally the fruit shape is elongate, fruit shape at blossom end is mostly pointed and ripe fruit 
pungency is low. In the Antakya-Yayladağ1-Altinözü group, the fruit shape is generally elongate, triangular or blocky, fruit shape at blossom end is blunt, pointed or sunken, soluble solids content is generally greater than the other groups and ripe fruit pungency is higher than Arsuz group. In the case of Samandag pepper, the variation is lower than the other groups, in general the fruit shape is elongate, fruit shape at blossom end is pointed, and ripe fruit pungency is higher than the other groups.

\footnotetext{
${ }^{* *}$ Çalışma, Prof. Dr. Sebahattin ÇÜRÜK danışmanlığında yürütülen Gonca ÖNTÜRK'ün 2018 yılında tamamlanan yüksek lisans tezinden üretilmiştir.
}

\section{Giriş}

Kültüre alınan 5 biber türünden en yaygın olan Capsicum annuum'un anavatanının Orta ve Güney Amerika (Hancock, 1992) olduğu bilinmektedir. Keleş ve ark. (2016)'nın bildirdiğine göre Andrews (1999), biberin Antakya üzerinden Anadolu'ya girdiğini belirtmektedir. Türkiye, 2012-2016 verilerine göre yıllık 2195872 tonluk üretimiyle Dünya biber üretici ülkeleri arasında Çin ve Meksika'dan sonra 3. sırada yer almaktadır (FAO, 2017). Akdeniz Bölgesinin bu yıllardaki ortalama biber üretimi 787756 tondur. Türkiye'de en çok (\% 35.17) biber üreten bölge olan Akdeniz Bölgesi'nde 3. sirada bulunan Hatay, 62810 ton biber üretmektedir. Bu üretimin \% 62.74'ünü salçalık, \% 31.32'sini sivri biber ve \% 5.94'ünü dolmalık biber oluşturmaktadır. 2013-2016 yılları ortalama verilerine göre Hatay'da en çok biber üretimi sırasıyla Antakya, Samandağ, Arsuz, Altınözü ve Yayladağı ilçelerinde yapılmaktadır (TÜİK, 2017).

Çeşitli yemek, meze, salça, turşu, sos, közlenmiş biber konservesi, toz ve pul biber gibi ürünlerin yapımında kullanılan biber, $A$ ve $C$ vitaminleri yönünden oldukça zengin, $\beta$-karoten değeri de yüksek bir sebzedir. Biber aynı zamanda demir, magnezyum, mangan, fosfor, bakır ve potasyum gibi minerallerin iyi bir kaynağıdır. Acılık Capsicum'un özgün bir özelliği olmakla birlikte, bütün Capsicum türleri acı değildir (Liu ve ark., 2013). Biberde acılığın oluşmasını sağlayan bileşikler kapsaisinoidler olup, bunların en yaygını kapsaisindir. Kapsaisinoid bileşiklerinin bitki dokularındaki toplam değeri değişiklik göstermekle birlikte kapsaisin ve dihidrokapsaisin oranları, C. апnиum türünde \% 77-90, C. frutescens türünde ise \% 89-98 arasında değişkenlik göstermektedir (Govindarajan ve ark. (1987)'dan İşlek, 2009). Dolayısıyla bu iki kapsaisinoid biberde analiz edilerek, acılık büyük oranda belirlenebilir.

Ülkemizde, genetik kaynakların toplanması, karakterizasyonu ve muhafazası ile ilgili ilk çalışmaların yabancı araştırmacılar tarafından yapıldı̆̆ 1 , bazı araştırmacıların 1930'lu ve 1940'lı yıllarda Türkiye'nin birçok bölgesinde sürvey çalışmaları yaparak mevcut yerel sebze tohumlarımızı ABD'ye götürdükleri bildirilmiştir (Karaağaç ve Balkaya, 2017). Türkiye'de Bitki Araştırma ve İntrodüksiyon Merkezinin kurulmasıyla 1964 yılından itibaren toplamaların sistemli bir şekilde günümüze kadar devam ettiği belirtilmiştir (Aykaş ve ark., 2016). En fazla biber, kavun, domates, bakla ve karpuz türlerinde gen kaynağı toplama çalışmaları yapıldığı bildirilmiştir. Ülkemizde genetik kaynakların toplanması ve karakterizasyonu konusunda çok sayıda çalışma (Alan, 1984; Duman ve Düzyaman, 2004; Keleş, 2007; Mutlu ve ark., 2009; Bozokalfa ve Eşiyok, 2010; Karaağaç ve Balkaya, 2010; Binbir ve Baş, 2010; Baysal, 2013; Çürük ve ark., 2015) yapılmıştır. Ayrıca, Dünyada benzer çalışmaların (Costa ve ark., 2015; Heinrich ve ark., 2015; Silva ve ark., 2015; Ulhoa ve ark., 2017) gerçekleştirilmesine devam edildiği görülmektedir.

Türkiye'nin kendine has coğrafi konumu ve çeşitli iklim kuşağında olması nedeniyle, coğrafi işarete konu olabilecek çok çeşitli ürünlere sahip olduğu bilinmektedir. Bu ürünlerin coğrafi işaret korumasıyla, üreticilere koruma sağladığı, pazarlama olanaklarını arttırdığı ve ekonomik getiri sağlayarak kırsal kalkınmayı desteklediği şeklinde avantajlarının bulunduğu belirtilmiştir (Gökovalı, 2007). Ülkemizde belirli yörelere ait olan bazı sebze çeşitlerinin, yerel yönetimin desteği ile coğrafi işaret tescili aldığı bildirilmiştir. Türk Patent Enstitüsü tarafından coğrafi işaret tescili verilen ürünler arasında Maraş Biberi, Şanlıurfa Biberi ve Denizli Kale Biberi olduğu belirtilmiştir (Karaağaç ve Balkaya, 2017). Hatay'ın özellikle Antakya, Altınözü, Yayladağı, Arsuz ve Samandağ ilçelerinde yetiştirilen Hatay biberi popülasyonları, coğrafi işaret tesciline konu olabilecek potansiyele sahiptir (Çürük ve ark., 2015). Ancak literatürde, bu biberin özellikleri hakkında yeterli bilgiye 
rastlanmamaktadır. Bu çalışmada, Hatay yöresel biberi köy popülasyonlarında bitki, çiçek ve meyve özellikleri belirlenerek mevcut varyasyonun ortaya çıkarılması amaçlanmıştır.

\section{Materyal ve Yöntem}

Hatay biberi üretimi istatistiklerine göre, yetiştiricilikte öne çıkan Arsuz ilçesinin Yukarıkepirce, Madenli ve Üçgüllük, Antakya'ya bağlı Demirköprü, Apaydın, Bohşin ve Avsuyu, Altınözü ilçesinin Hacıpaşa, Yarseli, Yolağzı, Kıyı̈ören ve Boynuyoğun, Yayladağı ilçesinin Çabala, Aşağıpulluyazı ve Güveçci ile Samandağ'ın Yeşilada mahallesinde, farklı çiftçilerin yetiştirdiği biber bahçelerinden toplam 16 biber köy popülasyonunun bitki ve meyve örnekleri materyal olarak kullanılmıştır.

Bu çalışma, 2016-2017 yılları arasında yukarda belirtilen biber yetiştirme alanlarında ve Hatay Mustafa Kemal Üniversitesi Ziraat Fakültesi, Bahçe Bitkileri Bölümüne ait laboratuvarlarda yürütülmüștür. Hatay biberi köy popülasyonlarının tohum üretimi, fide yetiştiriciliği ve dikimi, gübrelenmesi ile bakım işlemleri çiftçiler tarafından yapılmıştır. Belirlenen çiftçilerin ziyareti fide üretimi, dikimi ve bakım işlemleri döneminde (Ocak-Nisan 2016) gerçekleştirilmiştir. Her çiftçi kendi yetiştiricilik yöntemini uygulamış olup, yetiştiricilik yapılan yerin coğrafi konumu, toprak yapısı ve iklim değerleri, yetiştirme tekniği (fide yetiştiriciliği, dikim, gübreleme, sulama, bakım işlemleri vb.) bakımından, biber üretim alanları arasında farklılıklar bulunmaktadır. Çiftçiler, bir önceki yıl yetiştiricilik yaptıkları alanda en çok beğendikleri bitki veya meyvelerden tohumluk almaktadırlar. Çiftçilerin geneli tohumdan fide üretimi döneminde, toprağa yanmış çiftlik gübresini karıştırıp kullanmaktadır. Tohum ekimi, plastik tünellerde çiftlik gübresi karıştırılmış toprak veya viyollere doldurulmuş torf kullanılarak şubat ayının ilk iki haftasında yapılmaktadır. Dikim işlemi öncesi, genelde 20-25 kg da ${ }^{-1}$ taban gübresi (20-20-20 veya 15-15-15) uygulaması yapılarak, toprak yüzeysel işleme aletleriyle işlenmektedir. Mart ayının son haftası veya nisan ayının ilk haftasında fidelerin araziye dikim işlemi yapılmaktadır. Fideler, dikim yapılacağ 1 zaman, fidelikten sökülüp fidelerin çıplak kökleri, köklendirici veya bazı fungusit ilaçları ile hazırlanmış çözeltilere batırılarak veya hiçbir uygulama yapılmadan $70 \mathrm{~cm}$ sira arası, $20-25 \mathrm{~cm}$ sira üzeri olacak şekilde arazideki yerlerine dikilmektedir. Üst gübreleme olarak, genelde $25-30 \mathrm{~kg} \mathrm{da}^{-1}$ Amonyum sülfat gübresi uygulanmaktadır. Sulama, genelde karık sulama şeklinde yapılmaktadır. Ancak damla sulama ile sulama yapan çiftçiler de vardır.

\section{1. İncelenen özellikler ve verilerin değerlendirilmesi}

Popülasyonların incelenmesi amacıyla gerçekleştirilen bitki ve çiçek gözlemleri için materyal kısmında verilen mahallelerde belirlenen her biber bahçesinin 3 farklı yerinden işaretlenen, kökboğazı yanıklığı (Arpacı ve ark., 2016) ve virüs hastalık belirtisi göstermeyen, üzerinde yeşil ve kırmızı olum döneminde meyveleri bulunan toplam 21 bitki (3x7) kullanılmıştır. İşaretlenen bitkiler kullanılarak; bitki büyüme modeli (3: yatık, 5: kompakt, 7: dik, 9: diğer), gövde tüylülüğü (0: tüysüz, 3: az tüylü, 5: orta derecede tüylü, 7: çok tüylü), gövde rengi (1: yeşil, 3: mor çizgili yeşil, 5: mor), gövde şekli (1: silindirik, 2: üçgen, 3: düz), boğum rengine bağlı olarak bitkide antosiyanin oluşumu (1: yeşil, 3: açık mor, 5: mor, 7: koyu mor), yaprak rengi (1: sarı, 2: açık yeşil, 3: yeşil, 4: koyu yeşil, 5: açık mor, 6: mor, 7: karışık), yaprak şekli (1: yuvarlak, 2: oval, 3: dişli-sivri), yaprak tüylülüğü (0: tüysüz, 3: az tüylü, 5: orta derecede tüylü, 7: çok tüylü), koltuktaki çiçek sayısı (adet), çiçek pozisyonu (3: sarkık, 5: yarı dik, 7: dik) ve taç yaprak rengi (1: beyaz, 2: yeşil beyaz, 3: eflatun, 4: mavi, 5: menekşe, 6: diğer renkler) özellikleri incelenmiştir (Anonim, 1983; Anonim, 1995).

İncelenen popülasyonların meyve gözlem ve analizleri, 3 yenileme ve her yenilemede 7 bitkiden alınan kırmızı olum dönemindeki genelde 7 meyvede gerçekleştirilmiştir. Meyve gözlem ve analizleri kapsamında popülasyonların; meyve sapı ile çanak yaprağın birleştiği yerde boğum oluşumu (0: yok, 1: var), meyve sapının meyveye bağlanma şekli (1: dar, 3: küt, 5: düz, 7: yürek şeklinde, 9: loplu), meyve tabanında boyun oluşumu (0: yok, 1: var), çanak yaprak kenar şekli (3: düzgün, 5: orta dişli, 7: dişli), meyvenin çiçek ucu şekli (3: sivri, 5: kubbe, 7: çukur), meyve şekli (1: uzun, 2: oval, 3: yuvarlak, 4: konik, 5: çan şeklinde, 6: tombul), meyvede kopma tabakası (0: meyve sapı ve çanak yapraklar bitki üzerinde kalıyor, 1: sürekli), meyve uzunluğu (meyve sapı hariç) $(\mathrm{cm})$ ve genişliği $(\mathrm{mm})$, meyve sapı uzunluğu $(\mathrm{cm})$, meyve sapı kalınlığ $1(\mathrm{~mm})$, meyve et kalınlığı $(\mathrm{mm})$, meyve ağırlığı 
(g), tohum odac1k sayıs1 (adet), (Anonim, 1983; Anonim, 1995), meyve suyu pH değeri, suda çözünebilir kuru madde (SÇKM) (\%), titre edilebilir asitlik (\%), meyve kabuk ve et rengi, kapsaisin (ppm), dihidrokapsaisin ( $\mathrm{ppm})$ ve toplam kapsaisin-dihidrokapsaisin içeriği (ppm) gibi özellikleri belirlenmiştir. S1kılarak elde edilen meyve suyunun titre edilebilir asit oranı, Potansiyometrik yöntem (Sadler, 1994) ile belirlenmiş ve sitrik asit cinsinden \% olarak hesaplanmıştır. SÇKM (\%), el refraktometresi (Atago Model ATC-1E) ile tespit edilmiştir. Meyvelerin kabuk ve et rengi ölçümleri, C.I.E. (International Commission on Illumination) L*a*b*'ye göre Minolta CR-300 Chromometer renk ölçüm cihazı ile meyvenin orta kısmında; meyve kabuğu için üç taraftan, et rengi için tek taraftan okuma yapılarak gerçekleştirilmiş ve Abbott (1999)'a göre değerlendirilmiştir.

Kapsaisin ve dihidrokapsaisin analizi için meyve ektraksiyon örneklerinin hazırlanması: Meyve acılığını belirlemek üzere ekstraksiyon işlemi ve kapaisin analizi, HPLC ile Topaloğlu (2010)'na göre gerçekleştirilmiştir. Çalışmamızda meyve sapı, plasenta ve tohumları ayrılan meyveler $65^{\circ} \mathrm{C}$ 'ye ayarlanmış etüvde meyve ağırlığ 1 sabit kalıncaya kadar kurutulmuştur. Kurutulan örnekler kahve değirmeni (Bosch, MKM 6000, 220-230 V) ile öğ̈ütülerek toz haline getirilmişsir. Ekstraksiyon için sodyum asetat ile doyurulmuş \%95'lik etanol çözeltisi kullanılmıştır. $400 \mathrm{~mL}$ sodyum asetat ile doyurulmuş \%95'lik etanol çözeltisini oluşturmak amaciyla; $27.8 \mathrm{~g}$ sodyum asetat (Sigma-Aldrich, 25022), $380 \mathrm{~mL}$ etanol (Sigma-Aldrich, 34870) ve $10 \mathrm{~mL}$ ultra saf su içerisinde çözülmüştür. Ögütülmüş toz biber örneğinden $1 \mathrm{~g}$ alınarak $50 \mathrm{~mL}$ 'lik polipropilen tüplere (Corning) konulmuş ve üzerine sodyum asetat ile doyurulmuş \%95'lik etanolden $10 \mathrm{~mL}$ eklenmiştir. Hazırlanan örnekler, sıcaklığ $160^{\circ} \mathrm{C}$ 'ye ayarlanmış su banyosunda 3 saat bekletilmiştir. Ardından 40 dakika ultrasonik küvette degaz edilen örnekler, 2 numaralı Whatman kağıdından geçirilmiştir. Daha sonra $0.45 \mu \mathrm{m}$ 'lik filtre (Whatman, 1442125) ile ikinci kez süzülerek cam tüplere alınmıştır.

Kapsaisin ve dihidrokapsaisin standartlarının hazırlanması: Kapsaisin standartı olan NVanillylnonanamide'ten (Dr. Ehrenstorfer, C 17900600) $0.005 \mathrm{~g}$ tartılıp, $50 \mathrm{~mL}$ sodyum asetat ile doyurulmuş \%95'lik etanolde çözülerek 100 ppm $\left(\mu \mathrm{g} \mathrm{mL}^{-1}\right)^{\prime}$ lik stok çözeltisi elde edilmiştir. Daha sonra 5, 10, 20, 40 ve 80 ppm'lik standart çözeltileri hazırlanmıştır. Dihidrokapsaisin standartı (Sigma-Aldrich, 03813) kullanılarak, aynı konsantrasyonlarda dihidrokapsaisin standart çözeltileri de elde edilmiştir. HPLC sisteminde standartlar okutulmuş ve kalibrasyon işlemi gerçekleştirilmiştir.

HPLC sistemi için mobil faz hazırlanması ve HPLC koşulları: $1000 \mathrm{~mL}$ mobil faz oluşturmak amaciyla; $302 \mathrm{~mL}$ ultra saf su, $484 \mathrm{~mL}$ methanol (Merck, I850807 639), $133 \mathrm{~mL}$ 1-4 dioksan (Fisher Scientific, D/4550/PB17), 79 mL asetonitril (Chem-Lab, UN1648) ve $2 \mathrm{~mL}$ perklorik asit (Merck, B1209718) karıştırılmıştır (Topaloğlu, 2010). Hazırlanan mobil faz, ultrasonik küvette 30 dk bekletilerek degaz işlemi yapılmıştır. Daha sonra mobil faz HPLC sisteminde (SCL-10A vp, LC10AT vp, FCV-10AL vp, DGU-14A, CTU-10AS vp) kullanılmıştır. HPLC sisteminde kullanılan kolon C-18 (EC 250/4.6 Nucleosil 100-5 C18, Macherey-Nagel) özelliğindedir. Cihazın firın sıcaklığı $40^{\circ} \mathrm{C}$ olarak ayarlanmıştır. HPLC sisteminde SPD-M20A (PDA) dedektörü $280 \mathrm{~nm}$ 'de kullanılmıştır. Mobil faz akış hızı $1 \mathrm{~mL} \mathrm{dk}^{-1}$ olacak şekilde ayarlanmıştır. Yukarıda belirtildiği gibi hazırlanan biber meyve ekstrakt1, $20 \mu \mathrm{L}$ HPLC örnek yuvasına $50 \mu \mathrm{L}$ 'lik şırınga ile enjekte edildikten sonra 20-30 dk kromatogramda 6.8 ila $8.3 \mathrm{dk}$ arasında oluşan pikin alanı, kapsaisin standartı kullanıldığında aynı sürede meydana gelen pikin alanı ile mukayese edilerek kapsaisin miktarı (ppm) HPLC sistemi tarafından belirlenmiştir. Aynı şekilde kromatogramda 8.4 ila 10.2 dk arasında oluşan örnek pikin alanı ile dihidrokapsaisin standart çözeltisinin pik alanı karşılaştırılarak dihidrokapsaisin konsantrasyonu (ppm) saptanmıştır. Her örneğin her yenilemesindeki analizi, en az iki paralel olarak yapılmış ve ortalaması alınmıştır.

Yukarıda belirtildiği gibi belirlenen bitkiler ve kırmızı olum dönemindeki meyvelerde gerçekleştirilen ölçüm, analiz ve skala değerlerinin maksimum, minimum, ortalama, standart sapma (standart sapma.s) ve varyasyon katsayısı Microsoft Excell 2016 programı ile hesaplanmıştır.

\section{Bulgular}

\subsection{Hatay biberi köy popülasyonlarında bitki ve çiçek özellikleri}

Hatay'ın 5 ilçesinin farklı mahallelerinde incelenen 16 biber popülasyonunda bazı bitki özellikleri bakımından varyasyon olmadığı gözlemlenmiştir. Buna göre bitki büyüme modelinin dik, gövdenin tüysüz ve yeşil renkli, gövde şeklinin silindirik, yaprağın yeşil renkli, yaprağın oval ve 
tüysüz, koltuktaki çiçek sayısının 1 olduğu tespit edilmiştir (değerler verilmemiştir). Bitki boğumunda antosiyanin rengi bakımından, Altınözü popülasyonları dışında varyasyon olduğu ve antosiyanin renginin koyu mor veya mor renkte olduğu belirlenmiştir (Çizelge 1). Samandağ Yeşilada popülasyonu bitkilerinin yaklaşık \% 76'sında bitki boğumunda antosiyanin oluşmadığı, yeşil renk oluştuğu saptanmıştır. Ayrıca çiçek pozisyonu bakımından genotipler arasında farklılık gözlenmiştir (Çizelge 1). Çiçekler Kıyıgören ve Boynuyoğun popülasyonlarındaki bitkilerde sarkık, her üç çiçek pozisyonu gösteren Hacıpaşa, Demirköprü ve Apaydın genotipleri hariç diğer genotiplerde sarkık veya yarı dik olmuştur. Standart sapma ve VK değerlerine göre en yüksek varyasyon Hacıpaşa popülasyonunda belirlenmiş olup sarkık (\% 61.91), yarı dik (\% 4.76) ve dik (\% 33.33) çiçekler gözlenmiştir.

Çizelge 1. Farklı mahallelerde incelenen popülasyonlarda antosiyanin oluşumu ve çiçek pozisyonu özellikleriyle ilgili veriler

\begin{tabular}{|c|c|c|c|c|c|c|c|c|c|}
\hline \multirow[t]{2}{*}{ İlçe } & \multirow[t]{2}{*}{ Mahalle } & \multicolumn{4}{|c|}{ Bitki Boğumunda Antosiyanin ${ }^{1}$} & \multicolumn{4}{|c|}{ Çiçek Pozisyonu $^{2}$} \\
\hline & & Mak/Min & Ort & SS & VK & Mak/Min & Ort & SS & VK \\
\hline \multirow[t]{4}{*}{ Antakya } & Demirköprü & $7 / 5$ & 5.67 & 0.97 & 17.05 & $7 / 3$ & 3.86 & 1.35 & 35.06 \\
\hline & Apaydin & $7 / 5$ & 5.19 & 0.60 & 11.59 & $7 / 3$ & 4.14 & 1.20 & 28.85 \\
\hline & Bohşin & $7 / 5$ & 5.86 & 1.01 & 17.32 & $5 / 3$ & 3.10 & 0.44 & 14.10 \\
\hline & Avsuyu & $7 / 5$ & 5.67 & 0.97 & 17.05 & $5 / 3$ & 3.19 & 0.60 & 18.86 \\
\hline \multirow[t]{5}{*}{ Altınözü } & Hacıpaşa & $7 / 7$ & 7.00 & 0.00 & 0.00 & $7 / 3$ & 4.43 & 1.91 & 43.18 \\
\hline & Yarseli & $7 / 7$ & 7.00 & 0.00 & 0.00 & $5 / 3$ & 3.10 & 0.44 & 14.10 \\
\hline & Yolağzı & $7 / 7$ & 7.00 & 0.00 & 0.00 & $5 / 3$ & 3.19 & 0.60 & 18.86 \\
\hline & Kiy1gören & $7 / 7$ & 7.00 & 0.00 & 0.00 & $3 / 3$ & 3.00 & 0.00 & 0.00 \\
\hline & Boynuyoğun & $7 / 7$ & 7.00 & 0.00 & 0.00 & $3 / 3$ & 3.00 & 0.00 & 0.00 \\
\hline \multirow[t]{3}{*}{ Arsuz } & Yukarkkepirce & $7 / 5$ & 5.86 & 1.01 & 17.32 & $5 / 3$ & 3.48 & 0.87 & 25.11 \\
\hline & Madenli & $7 / 5$ & 5.29 & 0.72 & 13.57 & $5 / 3$ & 3.19 & 0.60 & 18.86 \\
\hline & Üçgüllük & $7 / 5$ & 5.29 & 0.72 & 13.57 & $5 / 3$ & 3.29 & 0.72 & 21.83 \\
\hline \multirow[t]{3}{*}{ Yayladağ $_{1}$} & Çabala & $7 / 5$ & 6.52 & 0.87 & 13.38 & $5 / 3$ & 3.48 & 0.87 & 25.11 \\
\hline & Aşağıpulluyazı & $7 / 5$ & 6.05 & 1.02 & 16.92 & $5 / 3$ & 3.76 & 1.00 & 26.46 \\
\hline & Güveçci & $7 / 5$ & 6.81 & 0.60 & 8.83 & $5 / 3$ & 3.38 & 0.80 & 23.80 \\
\hline Samandağ & Yeşilada & $5 / 1$ & 1.76 & 1.48 & 84.00 & $5 / 3$ & 3.19 & 0.60 & 18.86 \\
\hline
\end{tabular}

Mak/Min: Maksimum/Minimum, Ort: Ortalama, SS: Standart sapma, VK: Varyasyon katsayısı, '1(1: yeşil, 3: açık mor, 5: mor, 7: koyu mor), ${ }^{2}$ (3: sarkık, 5: yarı dik, 7: dik)

\subsection{Hatay biberi köy popülasyonlarında meyve özellikleri}

İncelenen bütün popülasyonlardan alınan tüm meyvelerde, meyve sapı ile çanak yaprak arasında boğum bulunduğu gözlenmiştir (Çizelge 2). Meyve sapının meyveye bağlanma şekli bakımından, en yüksek varyasyon, Yukarıkepirce mahallesinde incelenen genotipte belirlenmiş olup (Çizelge 2), değerlendirmeye alınan 21 meyveden 2'sinin loplu (skala değeri: 9), 3'ünün yürek (7), 9'unun düz (5) ve 7'sinin küt (3) şeklinde meyve sapına bağlandığ 1 belirlenmiştir. En düşük ortalama skala değeri ve varyasyon, meyve sapı bağlanma şekli \% 95.23 oranında küt (3) olan Çabala popülasyonunda saptanmıştır. İncelenen popülasyonlar arasında, meyve tabanında boyun oluşturmayan Hacıpaşa genotipi hariç, bütün popülasyonlarda söz konusu bu özellik bakımından varyasyon meydana gelmiştir (Çizelge 2). Standart sapması en yüksek olan Çabala ve Kıyıgören genotiplerinde $\% 23.81$ düzeyinde boyun oluşumu tespit edilmiştir.

Elde edilen verilere göre, meyve çanak yaprak kenar şekli bakımından en yüksek standart sapma ve varyasyon katsayısına sahip olan genotip, Çabala popülasyonudur (Çizelge 3). Bu genotipte $\% 23.81$ dişli, \% 47.62 orta dişli ve \% 28.57 düzgün çanak yaprak şekline sahip meyvelerin olduğu belirlenmiştir. En düşük varyasyon ise Bohşin ve Madenli mahallelerinden alınan örneklerde belirlenmiştir. Bu genotiplerde meyvelerin çoğunda çanak yaprak şekli orta dişli olarak belirlenmiş olmakla birlikte, \% 14.28 düzeyinde dişli çanak yaprak kenar şekli gözlenmiştir. 
Çizelge 2. İncelenen popülasyonlarda meyve sapı ile çanak yaprak arasında boğum oluşumu (MSÇYABO), meyve sapının meyveye bağlanma şekli (MSMBŞ) ve meyve tabanında boyun oluşumu (MTBO) özellikleriyle ilgili veriler

\begin{tabular}{|c|c|c|c|c|c|c|c|c|c|c|}
\hline \multirow[t]{2}{*}{ İlçe } & \multirow[t]{2}{*}{ Mahalle } & \multicolumn{2}{|c|}{ MSÇYABO $^{1}$} & \multicolumn{2}{|l|}{ MSMBŞ $^{2}$} & \multicolumn{5}{|c|}{$\mathrm{MTBO}^{3}$} \\
\hline & & Ort & $\mathrm{SS}$ & Mak/Min & Ort & SS & $\mathrm{VK}$ & Mak/Min & Ort & SS \\
\hline \multirow[t]{4}{*}{ Antakya } & Demirköprü & 1.00 & 0.00 & $5 / 3$ & 4.71 & 0.72 & 15.21 & $1 / 0$ & 0.10 & 0.30 \\
\hline & Apaydın & 1.00 & 0.00 & $5 / 3$ & 4.33 & 0.97 & 22.29 & $1 / 0$ & 0.05 & 0.22 \\
\hline & Bohşin & 1.00 & 0.00 & $5 / 3$ & 4.62 & 0.80 & 17.42 & $1 / 0$ & 0.10 & 0.30 \\
\hline & Avsuyu & 1.00 & 0.00 & $5 / 3$ & 4.05 & 1.02 & 25.29 & $1 / 0$ & 0.19 & 0.40 \\
\hline \multirow[t]{5}{*}{ Altınözü } & Hacıpaşa & 1.00 & 0.00 & $5 / 3$ & 4.14 & 1.01 & 24.48 & $0 / 0$ & 0.00 & 0.00 \\
\hline & Yarseli & 1.00 & 0.00 & $7 / 3$ & 4.81 & 0.87 & 18.15 & $1 / 0$ & 0.10 & 0.30 \\
\hline & Yolağzı & 1.00 & 0.00 & $5 / 3$ & 4.24 & 1.00 & 23.48 & $1 / 0$ & 0.05 & 0.22 \\
\hline & Kiyıgören & 1.00 & 0.00 & $5 / 3$ & 4.05 & 1.02 & 25.29 & $1 / 0$ & 0.24 & 0.44 \\
\hline & Boynuyoğun & 1.00 & 0.00 & $5 / 3$ & 4.33 & 0.97 & 22.29 & $1 / 0$ & 0.19 & 0.40 \\
\hline \multirow[t]{3}{*}{ Arsuz } & Yukarıkepirce & 1.00 & 0.00 & $9 / 3$ & 5.00 & 1.90 & 37.95 & $1 / 0$ & 0.10 & 0.30 \\
\hline & Madenli & 1.00 & 0.00 & $7 / 3$ & 3.86 & 1.20 & 30.99 & $1 / 0$ & 0.05 & 0.22 \\
\hline & Üçgüllük & 1.00 & 0.00 & $5 / 3$ & 3.29 & 0.72 & 21.83 & $1 / 0$ & 0.05 & 0.22 \\
\hline \multirow[t]{3}{*}{ Yayladağ 1} & Çabala & 1.00 & 0.00 & $5 / 3$ & 3.10 & 0.44 & 14.10 & $1 / 0$ & 0.24 & 0.44 \\
\hline & Aşağıpulluyazı & 1.00 & 0.00 & $7 / 3$ & 4.62 & 1.20 & 26.05 & $1 / 0$ & 0.05 & 0.22 \\
\hline & Güveçci & 1.00 & 0.00 & $7 / 3$ & 5.00 & 1.10 & 21.91 & $1 / 0$ & 0.10 & 0.30 \\
\hline Samandağ & Yeşilada & 1.00 & 0.00 & $5 / 3$ & 4.33 & 0.97 & 22.29 & $1 / 0$ & 0.10 & 0.30 \\
\hline
\end{tabular}

Mak/Min: Maksimum/Minimum, Ort: Ortalama, SS: Standart sapma, VK: Varyasyon katsayıs1, ${ }^{1}\left(0\right.$ : yok, 1: var ), ${ }^{2}(1:$ dar, 3 : küt, 5: düz, 7 : yürek şeklinde, 9: loplu), ${ }^{3}(0$ : yok, 1: var $)$

Çizelge 3. İncelenen popülasyonlarda çanak yaprak kenar şekli ve meyve çiçek ucu şekli özellikleriyle ilgili veriler

\begin{tabular}{|c|c|c|c|c|c|c|c|c|c|}
\hline \multirow[t]{2}{*}{ İlçe } & \multirow[t]{2}{*}{ Mahalle } & \multicolumn{4}{|c|}{ Çanak Yaprak Kenar Şekli ${ }^{1}$} & \multicolumn{4}{|c|}{ Meyve Çiçek Ucu Şekli ${ }^{2}$} \\
\hline & & Mak/Min & Ort & $\mathrm{SS}$ & $\mathrm{VK}$ & Mak/Min & Ort & $\mathrm{SS}$ & $\mathrm{VK}$ \\
\hline \multirow[t]{4}{*}{ Antakya } & Demirköprü & $7 / 3$ & 4.52 & 1.10 & 23.83 & $7 / 3$ & 5.29 & 1.71 & 32.30 \\
\hline & Apaydın & $7 / 3$ & 4.91 & 1.18 & 24.04 & $7 / 3$ & 4.90 & 1.95 & 39.69 \\
\hline & Bohşin & $7 / 5$ & 5.29 & 0.72 & 13.57 & $7 / 3$ & 4.52 & 1.78 & 39.31 \\
\hline & Avsuyu & $7 / 3$ & 5.38 & 1.20 & 22.36 & $7 / 3$ & 3.95 & 1.36 & 34.39 \\
\hline \multirow[t]{5}{*}{ Altınözü } & Hacıpaşa & $7 / 3$ & 5.10 & 1.18 & 23.14 & $7 / 3$ & 3.57 & 1.12 & 31.39 \\
\hline & Yarseli & $7 / 3$ & 4.43 & 1.12 & 25.32 & $7 / 3$ & 6.62 & 1.02 & 15.46 \\
\hline & Yolağzı & $7 / 3$ & 5.57 & 1.29 & 23.11 & $7 / 3$ & 5.19 & 1.89 & 36.36 \\
\hline & Kiyıgören & $7 / 3$ & 5.28 & 1.15 & 21.69 & $7 / 3$ & 4.71 & 1.59 & 33.63 \\
\hline & Boynuyoğun & $7 / 5$ & 5.57 & 0.93 & 16.62 & $7 / 3$ & 5.29 & 1.71 & 32.30 \\
\hline \multirow[t]{3}{*}{ Arsuz } & Yukarıkepirce & $7 / 3$ & 5.00 & 1.27 & 25.30 & $5 / 3$ & 3.29 & 0.72 & 21.83 \\
\hline & Madenli & $7 / 5$ & 5.29 & 0.72 & 13.57 & $7 / 3$ & 3.57 & 1.12 & 31.39 \\
\hline & Üçgüllük & $7 / 3$ & 5.57 & 1.21 & 20.12 & $7 / 3$ & 3.67 & 1.15 & 31.49 \\
\hline \multirow[t]{3}{*}{ Yayladağ 1} & Çabala & $7 / 3$ & 4.91 & 1.48 & 30.18 & $7 / 3$ & 4.14 & 1.49 & 36.03 \\
\hline & Așağıpulluyazı & $7 / 3$ & 4.81 & 1.25 & 25.99 & $7 / 3$ & 4.62 & 1.50 & 32.46 \\
\hline & Güveçci & $7 / 3$ & 5.29 & 1.31 & 24.77 & $7 / 3$ & 4.52 & 1.78 & 39.31 \\
\hline Samandağ & Yeşilada & $7 / 5$ & 5.95 & 1.02 & 17.20 & $5 / 3$ & 3.10 & 0.44 & 14.10 \\
\hline
\end{tabular}

Mak/Min: Maksimum/Minimum, Ort: Ortalama, SS: Standart sapma, VK: Varyasyon katsayısı, ${ }^{1}$ (3: düzgün, 5: orta dişli, 7: dişli), ${ }^{2}$ (3: sivri, 5: kubbe, 7: çukur)

Meyve çiçek ucu şekli bakımından en yüksek varyasyon Apaydın, en düşük ise Yeşilada mahallesinden alınan örneklerde belirlenmiştir (Çizelge 3). Apaydın'dan alınan meyvelerin çiçek ucunun sırasıyla \% 9.52, \% 47.62 ve \% 42.86 oranında kubbe, sivri ve çukur şeklinde olduğu tespit edilmiştir. Yeşilada mahallesindeki popülasyonda meyvenin çiçek ucu şeklinin, \% 95.24 düzeyinde sivri olduğu saptanmıştır. En yüksek skala değerine sahip Yarseli'den alınan meyvelerin \% 85.71'inin çiçek ucu şekli çukur olarak belirlenmiştir.

Meyve şekli bakımından, standart sapması ve varyasyon katsayısı en yüksek genotipler sırasıyla Yarseli (2.49) ve Bohşin (104.58) olarak belirlenmiştir (Çizelge 4). Bohşin'de meyvelerin \% 85.71 'i uzun ve \% 14.29'u tombul olmuştur. Bununla birlikte, Yarseli mahallesinden alınan biber meyvelerinin incelenmesi sonucu 11'inin uzun, 9'unun tombul ve 1'inin konik biber şeklinde olduğu tespit edilmiş̧ir. Yeşilada ve Çabala popülasyonlarında meyve şeklinin uzun olduğu ve varyasyon gözlenmediği belirlenmiştir. Ayrıca incelenen bütün popülasyonlarda meyve sapı ve çanak yaprağın meyve üzerinde kaldığ (meyve sapı-çanak yaprağın ve meyvenin sürekli olduğu) belirlenmiş olup, bu özellikte varyasyonun olmadığı saptanmıştır (Çizelge 4). Alınan 16 biber popülasyonu incelendiğinde, ortalama meyve uzunluğunun $13.36 \mathrm{~cm}$ (Hacıpaşa) ila $21.08 \mathrm{~cm}$ (Yukarıkepirce) arasında değiştiği görülmektedir (Çizelge 4). Bu özellik ile ilgili olarak genotiplere ait standart sapma ve VK 
değerlerinin incelenmesi sonucu, en geniş varyasyon Güveççi ve Apaydın popülasyonlarında, en düşük varyasyon ise Yeşilada genotipinde saptanmıştır.

Çizelge 4. İncelenen popülasyonlarda meyve şekli, meyvede kopma tabakası (MKT) ve meyve uzunluğu verileri

\begin{tabular}{|c|c|c|c|c|c|c|c|c|c|c|c|}
\hline \multirow[t]{2}{*}{ İlçe } & \multirow[t]{2}{*}{ Mahalle } & \multicolumn{4}{|c|}{ Meyve Şekli ${ }^{1}$} & \multicolumn{2}{|c|}{$\mathrm{MKT}^{2}$} & \multicolumn{4}{|c|}{ Meyve Uzunluğu (cm) } \\
\hline & & Mak & Ort & SS & VK & Ort & SS & Mak/Min & Ort & SS & VK \\
\hline \multirow[t]{4}{*}{ Antakya } & Demirköprü & $6 / 1$ & 2.10 & 2.05 & 97.70 & 1.00 & 0.00 & $23.80 / 7.70$ & 16.40 & 3.90 & 23.77 \\
\hline & Apaydın & $6 / 1$ & 1.52 & 1.36 & 89.55 & 1.00 & 0.00 & $28.80 / 10.90$ & 17.72 & 4.78 & 26.98 \\
\hline & Bohşin & $6 / 1$ & 1.71 & 1.79 & 104.58 & 1.00 & 0.00 & $23.30 / 7.10$ & 17.82 & 3.54 & 19.83 \\
\hline & Avsuyu & $6 / 1$ & 1.48 & 1.50 & 101.88 & 1.00 & 0.00 & $23.60 / 11.50$ & 17.13 & 3.19 & 18.61 \\
\hline \multirow[t]{5}{*}{ Altınözü } & Hacıpaşa & $4 / 1$ & 1.29 & 0.90 & 70.18 & 1.00 & 0.00 & $17.30 / 9.60$ & 13.36 & 1.89 & 14.16 \\
\hline & Yarseli & $6 / 1$ & 3.29 & 2.49 & 75.87 & 1.00 & 0.00 & $25.20 / 11.20$ & 17.94 & 3.62 & 20.18 \\
\hline & Yolağz1 & $6 / 1$ & 2.38 & 2.09 & 87.57 & 1.00 & 0.00 & $21.30 / 11.70$ & 16.05 & 2.85 & 17.73 \\
\hline & Kiyıgören & $6 / 1$ & 1.38 & 1.24 & 90.09 & 1.00 & 0.00 & $24.30 / 11.30$ & 17.77 & 3.38 & 19.00 \\
\hline & Boynuyoğun & $6 / 1$ & 1.38 & 1.24 & 90.09 & 1.00 & 0.00 & $27.50 / 11.70$ & 18.01 & 4.47 & 24.84 \\
\hline \multirow[t]{3}{*}{ Arsuz } & Yukarıkepirce & $4 / 1$ & 1.14 & 0.65 & 57.28 & 1.00 & 0.00 & $28.40 / 14.10$ & 21.08 & 3.58 & 17.00 \\
\hline & Madenli & $4 / 1$ & 1.14 & 0.65 & 57.28 & 1.00 & 0.00 & $23.20 / 13.10$ & 17.39 & 3.21 & 18.44 \\
\hline & Üçgüllük & $6 / 1$ & 1.38 & 1.24 & 90.09 & 1.00 & 0.00 & $20.10 / 9.60$ & 15.23 & 3.30 & 21.69 \\
\hline \multirow[t]{3}{*}{ Yayladağ1 } & Çabala & $1 / 1$ & 1.00 & 0.00 & 0.00 & 1.00 & 0.00 & $24.30 / 12.90$ & 18.35 & 3.02 & 16.47 \\
\hline & Aşağıpulluyazı & $4 / 1$ & 1.29 & 0.90 & 70.18 & 1.00 & 0.00 & $26.80 / 12.40$ & 16.99 & 3.73 & 21.96 \\
\hline & Güveçci & $6 / 1$ & 1.95 & 1.60 & 81.75 & 1.00 & 0.00 & $28.50 / 11.50$ & 19.52 & 5.00 & 25.62 \\
\hline Samandağ & Yeşilada & $1 / 1$ & 1.00 & 0.00 & 0.00 & 1.00 & 0.00 & $20.20 / 16.20$ & 18.21 & 1.14 & 6.29 \\
\hline
\end{tabular}

Mak/Min: Maksimum/Minimum, Ort: Ortalama, SS: Standart sapma, VK: Varyasyon katsayıs1, ${ }^{1}$ (1: uzun, 2: oval, 3: yuvarlak, 4: konik, 5: çan şeklinde, 6 : tombul), ${ }^{2}$ (0: meyve sapı ile çanak yaprağın bitki üzerinde kalması, 1: sürekli)

Araştırma kapsamında değerlendirmeye alınan biber popülasyonlarında en geniş meyveler (42.33 ve $42.23 \mathrm{~mm}$ ) Yarseli ve Güveçci mahallelerinde, en dar $(26.64 \mathrm{~mm})$ meyveler Çabala mahallesinde saptanmıştır (Çizelge 5). Genotiplerin meyve genişliği standart sapma ve VK değerlerine göre Yarseli, Boynuyoğun, Yukarıkepirce ve Güveçci genotipinde yüksek varyasyon, Hacıpaşa, Çabala ve Yeşilada genotiplerinde ise düşük varyasyon belirlenmiştir. Çizelge 5 'te verilen ortalama değerlere göre incelenen popülasyonlar arasında, en uzun $(5.75 \mathrm{~cm})$ meyve sap1 Yarseli mahallesinden ve en kısa $(3.45 \mathrm{~cm})$ meyve sapı ise Hacıpaşa mahallesinden alınan bitkilerde saptanmıştır. Sap uzunluğunun standart sapma ve VK değerlerine bakıldığında, varyasyonun en az Yeşilada genotipinde ve en fazla Güveççi popülasyonunda olduğu görülmektedir. Meyve sap kalınlığı ölçümlerinde ise en yüksek $(7.02 \mathrm{~mm})$ ortalama değerin Yarseli'de, en düşük $(5.18 \mathrm{~mm})$ değerin Yukarıkepirce'de olduğu belirtilmiştir (Çizelge 5). Standart sapma ve VK değerlerine göre, meyve sapı kalınlığı bakımından varyasyonun Boynuyoğun genotipinde en fazla, Hacıpaşa genotipinde ise en düşük olduğu saptanmıştır.

Çizelge 5. İncelenen popülasyonlarda meyve genişliği, meyve sap uzunluğu ve meyve sap kalınlığı özellikleriyle ilgili veriler

\begin{tabular}{|c|c|c|c|c|c|c|c|c|c|c|c|c|c|}
\hline \multirow[t]{2}{*}{ İlçe } & \multirow[t]{2}{*}{ Mahalle } & \multicolumn{4}{|c|}{ Meyve Genişliği (mm) } & \multicolumn{4}{|c|}{ Meyve Sap Uzunluğu $(\mathrm{cm})$} & \multicolumn{4}{|c|}{ Meyve Sap Kalınlığı (mm) } \\
\hline & & Mak/Min & Ort & SS & VK & Mak/Min & Ort & SS & VK & Mak/Min & Ort & SS & VK \\
\hline \multirow[t]{4}{*}{ Antakya } & Demirköprü & $48.50 / 27.30$ & 36.30 & 5.75 & 15.85 & $7.10 / 3.70$ & 4.94 & 0.90 & 18.29 & $8.70 / 5.10$ & 6.60 & 0.93 & 14.12 \\
\hline & Apas & $40.10 / 24.80$ & 31.56 & 4.28 & 13.55 & $7.20 / 3.30$ & 4.98 & 1.08 & 21.67 & $6.90 / 4.40$ & 5.78 & 0.78 & 13.48 \\
\hline & Bohssin & $43.20 / 26.70$ & 34.21 & 4.53 & 13.24 & $6.70 / 3.10$ & 4.76 & 0.84 & 17.70 & & 6.36 & 0.99 & 15.51 \\
\hline & Avsuyu & $37.70 / 22.50$ & 30.64 & 4.38 & 14.29 & & 5.49 & 1.20 & & & 6.02 & 0.70 & \\
\hline \multirow[t]{5}{*}{ Altınözü } & Hac1 & 38.8 & 32.13 & 3.26 & 10.13 & & 3.45 & & & & 5.95 & 0.52 & 8.80 \\
\hline & Yars & 77 & 42.33 & & & & 5.75 & & & & 7.02 & 1 & 15.79 \\
\hline & Yola & 70 & 34.74 & 5.60 & 16.13 & 6.40 & 4.92 & & & 90 & 6.29 & 0.87 & 13.89 \\
\hline & $\mathrm{K}_{1}$ & & 30.83 & 5.38 & 17.45 & 30 & 5.03 & & 77 & 60 & 6.25 & 8 & 17.33 \\
\hline & & & 33.21 & 7.13 & 21.47 & 50 & 5.30 & & 6 & 1.80 & 6.53 & .33 & 20.41 \\
\hline \multirow[t]{3}{*}{ Arsuz } & $\mathrm{Yu}$ & 21 & 31.68 & 8.24 & 26.02 & 90 & 5.17 & 0 & 15.41 & 76 & 5.18 & 0.85 & 16.37 \\
\hline & & 10 & 33.93 & 5.66 & 16.69 & 80 & 5.20 & 2 & 17 & 32 & 6.04 & 1.07 & 17.64 \\
\hline & & & 28.65 & 5.81 & 20.28 & & 4.07 & 1.02 & 25.03 & & 5.43 & 0.83 & 15.38 \\
\hline \multirow[t]{3}{*}{ Yayladağ 1} & Çabala & 32.3 & 26.64 & 3.09 & 11.61 & 5.90 & 4.18 & 0.82 & 19.65 & .20 & 5.97 & 1.05 & 17.53 \\
\hline & Aşağıpu & 48.4 & 37.50 & 6.27 & 16.72 & & 4.44 & 0.88 & 19.79 & & 5.59 & 1.11 & 19.88 \\
\hline & & 60.8 & 42.23 & 10.26 & 24.29 & 9.60 & 5.42 & & 26.54 & 9.30 & 6.09 & 1.20 & 19.73 \\
\hline Samandağ & Yeşilada & $38.98 / 27.63$ & 32.52 & 3.01 & 9.26 & $5.80 / 4.40$ & 5.03 & 0.34 & 6.78 & $7.21 / 4.97$ & 5.91 & 0.65 & 10.92 \\
\hline
\end{tabular}

Mak/Min: Maksimum/Minimum, Ort: Ortalama, SS: Standart sapma, VK: Varyasyon katsayıs1 
Meyve et kalınlığı ortalama verileri incelendiğinde en kalın etli $(3.28 \mathrm{~mm})$ meyvelerin Yolağzı popülasyonundan alınan bitki örneklerinde olduğu görülmüştür (Çizelge 6). Kıyıgören genotipinde ölçülen ortalama meyve et kalınlığının $(2.34 \mathrm{~mm})$ ise en ince olduğu belirlenmiştir. Değerlendirilen 16 biber örneği arasında orta kalınlıkta $(3.07 \mathrm{~mm})$ meyve etine sahip olan Yeşilada genotipinde, en az varyasyon oluşmuştur. Bu özellik açısından en geniş varyasyonun Güveçci popülasyonunda olduğu belirlenmiştir. İncelenen genotipler arasında en yüksek ortalama meyve ağırlığı (78.76 g) Yarseli popülasyonunda belirlenirken, Çabala $(37.73 \mathrm{~g})$ ve Üçgüllük $(37.75 \mathrm{~g})$ genotiplerinde diğer genotiplere kıyasla daha düşük ortalama meyve ağırlı̆̆ tespit edilmiştir (Çizelge 6). Bu karaktere ait VK'nın Yukarıkepirce popülasyonunda en yüksek, Yeşilada genotipinde ise en düşük olduğu saptanmıştır. Tohum odacık sayısı bakımından, Kıyıgören ve Yukarıkepirce popülasyonları yüksek varyasyon göstermiştir (Çizelge 6). Kıyıgören genotipinde tohum odacık sayısının, farklı bitkilerdeki meyvelere bağlı olarak 5 (\% 4.76), 4 (\% 28.57), 3 (\% 38.10), 2 (\% 23.81) ve 1 (\% 4.76) adet olduğu belirlenmiştir. Popülasyonlar arasında en düşük ortalama tohum odacık sayısına ve standart sapma değerine sahip olan Hacipaşa popülasyonu olmuştur. Bu genotipin meyvelerinde 2 (\% 61.90) veya 3 adet (\% 38.10) tohum odacığının bulunduğu tespit edilmiştir.

İncelenen popülasyonlardan alınan meyve suyu örneklerinde ölçülen $\mathrm{pH}$ değerlerinin 4.83 (Hacıpaşa) ila 5.59 (Boynuyoğun) arasında değiştiği saptanmıştır (Çizelge 7). Standart sapma ve VK değerlerine göre, bu karakter bakımından varyasyonun en fazla Yukarıkepirce popülasyonunda, en az Yolağzı genotipinde olduğu tespit edilmiştir. Değerlendirilen genotipler arasında en yüksek SÇKM (\% 9.0) Boynuyoğun mahallesinden alınan meyve örneklerinde, en düşük SÇKM (\% 6.47) ise Güveçci mahallesi meyvelerinde belirlenmiştir (Çizelge 7). SÇKM varyasyonunun Yolağzı mahallesinde en geniş, Yukarıkepirce mahallesinde en dar olduğu saptanmıştır.

Çizelge 6. İncelenen popülasyonlarda meyve et kalınlığı, meyve ağırlı̆ğ ve tohum odacık sayıs1 özellikleriyle ilgili veriler

\begin{tabular}{|c|c|c|c|c|c|c|c|c|c|c|c|c|c|}
\hline \multirow[t]{2}{*}{ İlçe } & \multirow[t]{2}{*}{ Mahalle } & \multicolumn{4}{|c|}{ Meyve Et Kalınlığ $1(\mathrm{~mm})$} & \multicolumn{4}{|c|}{ Meyve Ağırlı̆g $1(\mathrm{~g})$} & \multicolumn{4}{|c|}{ Tohum Odacık Sayısı (adet) } \\
\hline & & Mak/Min & Ort & SS & $\mathrm{VK}$ & Mak/Min & Ort & SS & $\mathrm{VK}$ & Mak/Min & Ort & $\mathrm{SS}$ & $\mathrm{VK}$ \\
\hline \multirow{4}{*}{ Antakya } & Demirköprü & $4.50 / 1.80$ & 2.94 & 0.77 & 26.07 & $80.52 / 40.97$ & 58.00 & 10.78 & 18.59 & $4 / 2$ & 3.29 & 0.64 & 19.59 \\
\hline & Apay & 4.50 & 2.77 & 0.85 & 30.55 & $73.05 / 32.82$ & 50.12 & 11.00 & 21.94 & $4 / 2$ & 3.10 & 0.83 & 26.85 \\
\hline & Bohşin & $30 / 2.10$ & 3.24 & 0.57 & 17.46 & $/ 30.28$ & 53.64 & & 28.77 & $4 / 2$ & 3.00 & 0.55 & 18.26 \\
\hline & Avs & 3.70 & 2.67 & 0.54 & 20.07 & 2.30 & 43.60 & & 27.66 & & 3.00 & 55 & .26 \\
\hline \multirow[t]{5}{*}{ Altınözü } & Hac1 & $3.80 /$ & 3.00 & 0.48 & 16 & 75.8 & 40.04 & & 26.35 & & 2.38 & & \\
\hline & Yars & & 2.98 & 0.77 & & 122 & 78.76 & & 31 & & 3.71 & & 5.09 \\
\hline & & & 3.28 & 0.74 & 22 & & 59.11 & & 3 & 2 & 0 & & 2.20 \\
\hline & & & 2.34 & 0.56 & & & 41 & & 26 & $5 /$ & 3.05 & & 1.94 \\
\hline & & & 2.86 & 0.80 & & & 59.05 & & 41 & 2 & 3.24 & & 9.30 \\
\hline \multirow[t]{3}{*}{ Arsuz } & $\mathrm{Yu}$ & 6 & 2.40 & 0.60 & 25 & 13 & 54.29 & 28 & 52 & $4 / 1$ & 2.67 & & .23 \\
\hline & & & 2.82 & 0.71 & 7 & 66 & 54.40 & 17 & 32 & 2 & 2.57 & 0 & 23.24 \\
\hline & Üç: & & 2.51 & 0.69 & 27 & & 37.75 & 9. & 23 & 2 & 2.62 & & 25.55 \\
\hline \multirow[t]{3}{*}{ Yayladağ } & 1Çabala & & 2.60 & 0.54 & 20.80 & 53 & 37.73 & 8. & 23.13 & 2 & 2.43 & 0.60 & 24.61 \\
\hline & Aşağıpull & & 2.77 & 0.58 & 20.89 & 5.84 & 57.36 & 22.28 & 38 & $4 / 2$ & 2.62 & 0.59 & 22.51 \\
\hline & Güveçci & & 3.15 & 1.01 & 31.97 & 37.16 & 76.32 & 28.00 & 36.69 & $4 / 1$ & 2.67 & 0.66 & 24.69 \\
\hline \multicolumn{2}{|c|}{ SamandağYeșilada } & $3.94 / 2.49$ & 3.07 & 0.45 & 14.83 & $82.01 / 47.96$ & 61.65 & 9.94 & 16.12 & $4 / 2$ & 2.86 & 0.65 & 22.9 \\
\hline
\end{tabular}

Ortalama titre edilebilir asitlik oranı en fazla (\% 0.433) Hacıpaşa popülasyonundan alınan biber meyvelerinde, en az (\% 0.247) Güveçci genotipi biber örneklerinde ölçülmüştür (Çizelge 7). Standart sapma ve VK değerlerine göre Yarseli ve Yeşilada popülasyonlarında yüksek, Bohşin, Üçgüllük ve Çabala genotiplerinde ise düşük varyasyon tespit edilmiştir. 
Çizelge 7. İncelenen popülasyonlarda pH, SÇKM ve titre edilebilir asitlik özellikleriyle ilgili veriler

\begin{tabular}{|c|c|c|c|c|c|c|c|c|c|c|c|c|c|}
\hline \multirow[t]{2}{*}{ İlçe } & \multirow[t]{2}{*}{ Mahalle } & \multicolumn{4}{|l|}{$\mathrm{pH}$} & \multicolumn{4}{|c|}{ SÇKM (\%) } & \multicolumn{4}{|c|}{ Titre Edilebilir Asitlik (\%) } \\
\hline & & Mak/Min & Ort & SS & VK & Mak/Min & Ort & SS & VK & Mak/Min & Ort & SS & VK \\
\hline \multirow[t]{4}{*}{ Antakya } & Demirköprü & $5.52 / 5.37$ & 5.46 & 0.08 & 1.42 & $8.20 / 6.80$ & 7.53 & 0.70 & 9.32 & $0.362 / 0.283$ & 0.312 & 0.044 & 14.05 \\
\hline & Apa & $5.47 / 4.40$ & 5.44 & 0.04 & 0.66 & $8.20 / 7.80$ & 8.00 & 0.20 & 2.50 & $0.371 / 0.331$ & 0.350 & 0.020 & 5.77 \\
\hline & Bohsin & $5.48 / 5.40$ & 5.45 & 0.04 & 0.76 & & 7.53 & 0.64 & 8.50 & 0.289 & & & 3.27 \\
\hline & & $53 / 5.40$ & 5.46 & 0.07 & 1.19 & & 8.27 & & 6.10 & 42 & 61 & & 10.18 \\
\hline \multirow[t]{5}{*}{ Altınözü } & $\mathrm{Hac}$ & 80 & 4.83 & 0.02 & 0.48 & 8.40 & 8.17 & 0.21 & 2.55 & 14 & 33 & 18 & 4.10 \\
\hline & & .52 & 5.55 & 0.05 & 0.83 & 7.8 & 7.07 & 0.81 & 11.44 & 49 & 02 & 47 & 15.43 \\
\hline & & 46 & 5.47 & 0.01 & 0.18 & 8.20 & 7.00 & 1.04 & 14.85 & 15 & 29 & 0.018 & 5.47 \\
\hline & & & 5.54 & 0.04 & 0.65 & 8.4 & 8.13 & 0.31 & 3.76 & & & 26 & 8.15 \\
\hline & & & 5.59 & 0.08 & 1.46 & 9.4 & 9.00 & 0.35 & 3.85 & & 0. & 0.015 & 4.24 \\
\hline \multirow[t]{3}{*}{ Arsuz } & ce & 01 & 5.20 & 0.26 & 5.01 & 7.00 & 6.87 & 0.12 & 1.68 & 73 & 0.282 & 0.014 & 4.94 \\
\hline & & 93 & 4.95 & 0.03 & 0.51 & 8.0 & 7.60 & 0.35 & 4.56 & 11 & & 0.016 & 4.94 \\
\hline & & & 4.93 & 0.04 & 0.77 & 7.80 & 6.93 & 0.81 & 11.66 & & 0.344 & 0.010 & 2.89 \\
\hline \multirow[t]{3}{*}{ Yayladağ1 } & Çabala & $5.59 / 5.52$ & 5.54 & 0.04 & 0.68 & $8.20 / 7.20$ & 7.60 & 0.53 & 6.96 & 298 & 0.310 & 0.011 & 3.59 \\
\hline & Aşağıpul & $5.53 / 5.49$ & 5.51 & 0.02 & 0.38 & $7.40 / 7.00$ & 7.20 & 0.20 & 7.78 & .275 & 0.288 & 0.012 & 4.10 \\
\hline & & $5.52 / 5.43$ & 5.49 & 0.05 & 0.95 & $7.20 / 5.80$ & 6.47 & 0.70 & 10.86 & $0.268 / 0.225$ & 0.247 & 0.022 & 8.70 \\
\hline Samandağ & Yeşilada & $4.94 / 4.83$ & 4.90 & 0.06 & 1.24 & $7.40 / 7.00$ & 7.20 & 0.20 & 2.78 & $0.361 / 0.268$ & 0.268 & 0.051 & 15.67 \\
\hline
\end{tabular}

Minolta ile sağlıklı olarak ölçümleri yapılabilen 10 popülasyonun meyve kabuk rengi verilerinde en yüksek ortalama L* değeri, yani en parlak kabuk rengi Apaydın popülasyonunda, en düşük parlaklık Yeşilada genotip meyvelerinde tespit edilmiştir (Çizelge 8). Bu özelliğin standart sapma ve VK değerlerine göre en geniş varyasyon Demirköprü popülasyonunda, en dar varyasyon ise Üçgüllük genotipinde saptanmıştır. Meyve kabuğu ortalama a* değerleri açısından en kırmızı kabuk renginin Yukarıkepirce popülasyonunda, en az kırmızı rengin Yeşilada genotipinde olduğu belirlenmiştir (Çizelge 8). Bu özellikte Kıyıgören, Madenli ve Yeşilada mahallelerinde yüksek varyasyon, Yukarıkepirce mahallesinde ise düşük varyasyon tespit edilmiştir. Meyve kabuğu ortalama b* değeri bakımından, Kıyı̈ören popülasyon meyvelerinden en yüksek, Yeşilada genotipinden ise en düşük değerler elde edilmiştir (Çizelge 8). Genotiplerin meyve kabuk $b^{*}$ değeri standart sapma ve VK verileri incelendiğinde, varyasyonunun Demirköprü popülasyonunda en fazla, Üçgüllük genotipinde en az olduğu görülmektedir.

Çizelge 8. İncelenen popülasyonlarda belirlenen meyve kabuğu L*, a* ve b* verileri

\begin{tabular}{|c|c|c|c|c|c|c|c|c|c|c|c|c|c|}
\hline \multirow[t]{2}{*}{$\overline{\text { İlçe }}$} & \multirow[t]{2}{*}{ Mahalle } & \multicolumn{4}{|l|}{$\mathrm{L}^{*}$} & \multicolumn{4}{|l|}{$a^{*}$} & \multicolumn{4}{|l|}{$\mathrm{b}^{*}$} \\
\hline & & Mak/Min & Ort & SS & VK & Mak/Min & Ort & SS & VK & MakMin & Ort & S & VK \\
\hline \multirow[t]{2}{*}{ Antakya } & könrï & 5.42 & 37.20 & 4.31 & 11.60 & 17.64 & 1.77 & 3.95 & 2.44 & 2.97 & 9.95 & 2 & 22.67 \\
\hline & & & 3 & & 8.26 & & & 2 & & & & & \\
\hline \multirow[t]{4}{*}{ Altınözü } & & & 37.05 & 2.61 & 7.03 & & & 3.04 & o & & & 77 & 97 \\
\hline & & & 33.64 & 1.93 & 5.74 & & 32.84 & 3.69 & 11.25 & & & 82 & 13.77 \\
\hline & & & 36.63 & 3.49 & 9.54 & & 33.37 & 5.83 & 17 & & & 75 & 14.17 \\
\hline & & & 36.73 & 4.00 & 10.89 & & 34.62 & 3.54 & 10.23 & & & 4.07 & 16.34 \\
\hline \multirow[t]{3}{*}{ Arsuz } & Yuka & $38.26 / 31.16$ & 34.90 & 2.02 & 5.79 & 39.8 & 35.15 & 2.18 & 6.20 & 25 . & 20.89 & 2.73 & 13.05 \\
\hline & & $39.45 / 31.92$ & 36.22 & 2.02 & 5.59 & 18.37 & 31.70 & 5.34 & 16.84 & 26.8 & 21.33 & 2.60 & 12.17 \\
\hline & Üç & $37.41 / 32.28$ & 35.48 & 1.49 & 4.21 & $39.43 / 30.42$ & 34.64 & 2.38 & 6.88 & $25.40 / 17.09$ & 20.84 & 2.30 & 11.02 \\
\hline \multicolumn{2}{|c|}{ SamandağYeşilada } & $37.95 / 30.45$ & 32.73 & 2.08 & 6.36 & $38.82 / 17.16$ & 28.34 & 5.28 & 18.65 & $20.98 / 9.91$ & 14.91 & 3.00 & 20.09 \\
\hline
\end{tabular}

Mak/Min: Maksimum/Minimum, Ort: Ortalama, SS: Standart sapma, VK: Varyasyon katsayısı, L*: Rengin parlaklığında meydana gelen renk değişimi, a*: Kırmızıdan yeşile renk değişimi, $b^{*}$ : Maviden sarıya renk değişimi

$C^{*}$ değerlerine göre Kıyı̈ören popülasyonu meyvelerinin kabuk rengi yoğunluğu en yüksek, Yeşilada genotip meyve kabuk rengi yoğunluğu ise en düşük olmuştur (Çizelge 9). Sözü edilen özellik bakımından varyasyonun Yeşilada'da geniş, Ǘçgüllük ve Yukarıkepirce popülasyonlarında dar olduğu saptanmıştır. Ortalama meyve kabuğu renk açı $\left(h^{0}\right)$ değeri en yüksek meyveler Kıyı̈ören popülasyonunda belirlenirken, en düşük açı değerine sahip meyveler Yarseli genotipinde tespit edilmiştir (Çizelge 9). Bu özelliğin standart sapma ve VK değerlerine göre Yeşilada mahallesinde en geniş, Üçgüllük mahallesinde en dar varyasyon saptanmıştır.

Meyve et rengi ölçümlerinde ortalama $L^{*}$ değerine göre en parlak meyve et rengi Kıyıgören biber örneklerinde, en az parlaklık Yeşilada genotip meyvelerinde belirlenmiştir (Çizelge 10). Bu özellik bakımından Demirköprü, Yarseli ve Boynuyoğun mahallelerinde geniş, Madenli mahallesinde 
dar varyasyon tespit edilmiştir. Ortalama meyve a* değerine göre en kırmızı et rengi Üçgüllük popülasyonu meyvelerinde, en az kırmızı et rengi Kıyıören genotipi meyve örneklerinde belirlenmiştir (Çizelge 10). Bu karakterin standart sapma ve VK değerleri Demirköprü'de en yüksek, Yeşilada'da en düşük olmuştur. Rengin parlaklığını belirleyen $L^{*}$ değerinde olduğu gibi meyve eti b* değeri, Kıyıgören popülasyonunda en yüksek, Yeşilada genotipinde en düşük olmuştur (Çizelge 10). Bu özellikte, en geniş varyasyon Yarseli'de, en dar varyasyon ise Kıyıgören'de belirlenmiştir.

Çizelge 9. Hatay ilçelerine bağlı farklı mahallelerde incelenen popülasyonlarda belirlenen meyve kabuğu $\mathrm{C}^{*}$ ve $h^{0}$ verileri

\begin{tabular}{|c|c|c|c|c|c|c|c|c|c|}
\hline \multirow[t]{2}{*}{$\overline{\text { İlçe }}$} & \multirow[t]{2}{*}{ Mahalle } & \multicolumn{4}{|l|}{$\mathrm{C}^{*}$} & \multicolumn{4}{|l|}{$h^{0}$} \\
\hline & & Mak/Min & Ort & SS & VK & $\mathrm{Mak} / \mathrm{Min}$ & Ort & SS & VK \\
\hline \multirow[t]{2}{*}{ Antakya } & Demirköprü & $43.70 / 30.26$ & 37.83 & 3.96 & 10.46 & $54.70 / 24.00$ & 31.98 & 7.27 & 22.75 \\
\hline & Apaydın & $48.13 / 31.27$ & 39.39 & 3.93 & 9.97 & $40.02 / 24.04$ & 30.44 & 4.42 & 14.51 \\
\hline \multirow[t]{4}{*}{ Altınözü } & Yarseli & $49.92 / 30.68$ & 39.19 & 4.16 & 10.63 & $40.29 / 24.51$ & 28.65 & 3.39 & 11.84 \\
\hline & Yolağzı & $46.07 / 27.33$ & 38.80 & 4.02 & 10.37 & $44.38 / 27.87$ & 31.96 & 3.71 & 11.60 \\
\hline & Kiyıgören & $54.38 / 35.82$ & 43.00 & 4.97 & 11.56 & $55.34 / 32.25$ & 38.81 & 6.51 & 16.78 \\
\hline & Boynuyoğun & $51.09 / 33.22$ & 42.56 & 4.53 & 10.64 & $45.23 / 29.52$ & 35.48 & 4.39 & 12.39 \\
\hline \multirow[t]{3}{*}{ Arsuz } & Yukarıkepirce & $47.13 / 36.79$ & 40.95 & 2.89 & 7.05 & $35.52 / 26.57$ & 30.58 & 2.72 & 8.91 \\
\hline & Madenli & $47.82 / 24.90$ & 38.32 & 5.40 & 14.09 & $45.51 / 28.22$ & 34.42 & 4.18 & 12.14 \\
\hline & Üçgüllük & $45.59 / 35.62$ & 40.47 & 2.84 & 7.03 & $37.14 / 27.73$ & 30.97 & 2.42 & 7.80 \\
\hline Samandağ & Yeşilada & $44.13 / 19.82$ & 32.27 & 5.70 & 17.66 & $60.97 / 24.14$ & 29.04 & 7.72 & 26.60 \\
\hline
\end{tabular}

Mak/Min: Maksimum/Minimum, Ort: Ortalama, SS: Standart sapma, VK: Varyasyon katsayısı, $\mathrm{C}^{*}$ : Rengin yoğunluğu, $h^{0}:$ Rengin açı değeri

Çizelge 10. İncelenen popülasyonlarda belirlenen meyve et rengi $\mathrm{L}^{*}, \mathrm{a}^{*}$ ve $\mathrm{b}^{*}$ verileri

\begin{tabular}{|c|c|c|c|c|c|c|c|c|c|c|c|c|c|}
\hline \multirow[t]{2}{*}{ İlçe } & \multirow[t]{2}{*}{ Mahalle } & \multicolumn{4}{|l|}{$\underline{L^{*}}$} & \multicolumn{4}{|l|}{$a^{*}$} & \multicolumn{4}{|l|}{$\mathrm{b}^{*}$} \\
\hline & & Mak/Min & Ort & SS & VK & Mak/Min & Ort & SS & VK & Mak/Min & Ort & SS & VK \\
\hline \multirow[t]{2}{*}{ Antakya } & Demirköprü & $60.67 / 36.20$ & 44.25 & 6.63 & 14.97 & $44.33 / 6.06$ & 35.16 & 8.89 & 25.29 & $45.15 / 26.95$ & 36.00 & 5.85 & 16.25 \\
\hline & Apaydın & 36.42 & 43.24 & 5.87 & 13.57 & $44.98 / 20.64$ & 39.07 & 6.32 & 16.18 & $42.44 / 26.19$ & 34.95 & 5.21 & 14.91 \\
\hline \multirow[t]{4}{*}{ Altınözü } & Yarseli & $54.89 / 29.62$ & 42.14 & 6.57 & 15.59 & $44.47 / 26.29$ & 38.61 & 4.86 & 12.58 & $52.64 / 18.60$ & 34.28 & 7.99 & 23.33 \\
\hline & Yolağzı & $51.72 / 25.96$ & 38.30 & 5.25 & 13.71 & $44.78 / 17.21$ & 37.62 & 5.55 & 14.75 & $56.59 / 27.43$ & 38.10 & 6.01 & 15.77 \\
\hline & Kiyıgören & 40.86 & 49.54 & 5.23 & 10.56 & $42.34 / 17.17$ & 34.65 & 7.01 & 20.24 & $54.43 / 39.92$ & 48.16 & 3.84 & 7.96 \\
\hline & yoğun & $58.88 / 33.62$ & 45.37 & 6.70 & 14.76 & $45.54 / 14.69$ & 36.53 & 8.23 & 22.53 & $59.78 / 35.97$ & 45.54 & 7.02 & 15.42 \\
\hline \multirow[t]{3}{*}{ Arsuz } & Yukarıkepirce & $46.62 / 32.43$ & 38.25 & 4.64 & 12.12 & $45.49 / 32.51$ & 40.53 & 3.63 & 8.95 & $46.72 / 24.04$ & 36.97 & 6.31 & 17.07 \\
\hline & Madenli & $46.71 / 35.50$ & 38.66 & 2.97 & 7.68 & $43.65 / 27.56$ & 38.55 & 3.72 & 9.66 & $48.66 / 33.17$ & 38.32 & 4.22 & 11.01 \\
\hline & Üçgüllük & $45.82 / 31.05$ & 37.54 & 3.42 & 9.11 & $45.26 / 29.83$ & 41.81 & 3.65 & 8.73 & $47.84 / 27.77$ & 38.04 & 5.74 & 15.08 \\
\hline Samandağ & Yeşilada & $43.29 / 29.71$ & 36.90 & 3.01 & 8.17 & $41.93 / 33.23$ & 38.92 & 2.45 & 6.29 & $38.30 / 21.68$ & 27.02 & 4.60 & 17.01 \\
\hline
\end{tabular}

Mak/Min: Maksimum/Minimum, Ort: Ortalama, SS: Standart sapma, VK:Varyasyon katsayısı, L*: Rengin parlaklığında meydana gelen renk değişimi, $a^{*}$ : Kırmızıdan yeşile renk değişimi, $b^{*}$ : Maviden sarıya renk değişimi

Renk yoğunluğunu belirleyen $C^{*}$ değerine göre meyve et rengi en yoğun olan biber örnekleri Kıyıgören ve Boynuyoğun popülasyonlarında, en az yoğun meyve et rengi ise Yeşilada genotipinde tespit edilmiştir (Çizelge 11). Varyasyonun, incelenen genotipler arasında Altınözü Yarseli popülasyonunda en fazla, Demirköprü genotipinde ise en az olduğu saptanmıştır. Ortalama meyve et rengi $h^{0}$ değeri, $\mathrm{L}^{*}, \mathrm{~b}^{*}$ ve $\mathrm{C}^{*}$ değerlerinde olduğu gibi en yüksek Kıyıgören mahallesinde, en düşük Yeşilada mahallesinde belirlenmiştir (Çizelge 11). Standart sapma ve VK değerlerine göre meyve et rengi $h^{0}$ değeri varyasyonunun, en geniş Demirköprü'de, en dar Madenli ve Yeşilada'da olduğu tespit edilmiştir.

Araştırmaya dahil edilen 16 biber popülasyonunun kurutulmuş meyve ekstraktı kullanılarak, HPLC sisteminin standart ve örneklerine ait kromotogramların karşılaştırılmasına bağlı olarak ölçülen ortalama kapsaisin ve dihidrokapsaisin içeriği incelendiğinde (Çizelge 12), popülasyonlardaki acıllı̆̆ belirleyen toplam kapsaisin-dihidrokapsaisin konsantrasyonun 879.45 ppm (Yeşilada) ila 37.27 ppm (Hacıpaşa) arasında değiştiği görülmektedir. Yeşilada popülasyonundan sonra Yolağzı (637.80 ppm) ve Avsuyu (607.67 ppm) genotipleri, diğer genotiplere kiyasla daha fazla toplam kapsaisin ve dihidrokapsaisin miktarına sahip olmuştur. Bu özellik açısından standart sapma değerinin Çabala ve Yeşilada genotiplerinde yüksek, Hacıpaşa popülasyonunda en düşük olduğu belirlenmiştir. VK değerleri dikkate alındığında, kapsaisin ve dihidrokapsaisin toplamı bakımından en geniş varyasyon Üçgüllük, en dar varyasyon ise Hacıpaşa genotipinde tespit edilmiştir. 
Çizelge 11. Hatay ilçelerine bağlı farklı mahallelerde incelenen popülasyonlarda belirlenen meyve et rengi $\mathrm{C}^{*}$ ve $h^{0}$ verileri

\begin{tabular}{llllllllll}
\hline İlçe & Mahalle & \multicolumn{2}{l}{$\mathrm{C}^{*}$} & \multicolumn{3}{l}{$h^{0}$} \\
\cline { 3 - 9 } & & Mak/Min & Ort & SS & VK & Mak/Min & Ort & SS & VK \\
\hline Antakya & Demirköprü & $57.64 / 44.60$ & 51.27 & 3.53 & 6.88 & $82.36 / 33.66$ & 46.01 & 11.75 & 25.55 \\
& Apaydın & $58.93 / 46.50$ & 52.87 & 4.08 & 7.72 & $64.06 / 33.37$ & 41.93 & 8.11 & 19.33 \\
Altınözüu & Yarseli & $64.48 / 36.02$ & 52.07 & 6.29 & 12.07 & $59.02 / 31.09$ & 41.15 & 7.57 & 18.38 \\
& Yolağzı & $65.68 / 40.15$ & 53.87 & 5.41 & 10.04 & $64.62 / 37.19$ & 45.35 & 6.78 & 14.95 \\
& Klyı̈̈ren & $65.74 / 48.88$ & 59.68 & 4.49 & 7.52 & $69.43 / 43.66$ & 54.52 & 6.59 & 12.10 \\
& Boynuyoğun & $69.33 / 47.50$ & 59.08 & 5.50 & 9.31 & $73.42 / 41.41$ & 51.27 & 9.25 & 18.03 \\
Arsuz & Yukarıkepirce & $63.58 / 40.43$ & 55.05 & 5.46 & 9.93 & $54.02 / 34.83$ & 42.10 & 5.05 & 12.00 \\
& Madenli & $64.46 / 47.71$ & 54.48 & 4.24 & 7.80 & $54.71 / 39.10$ & 44.81 & 3.93 & 8.76 \\
& Üçgüllük & $65.39 / 47.29$ & 56.74 & 4.65 & 8.19 & $55.07 / 35.18$ & 42.11 & 5.14 & 12.21 \\
Samandağy & Yeşilada & $55.61 / 39.68$ & 47.49 & 4.06 & 8.54 & $43.53 / 28.75$ & 34.56 & 3.86 & 11.16 \\
\hline
\end{tabular}

Mak/Min: Maksimum/Minimum, Ort: Ortalama, SS: Standart sapma, VK:Varyasyon katsayısı, C*: Rengin yoğunluğu, $h^{0}:$ Rengin açı değeri

Çizelge 12. İncelenen popülasyonlarda kuru ağırlı üzerinden HPLC ile belirlenen ortalama kapsaisin, dihidrokapsaisin ve toplam kapsaisin-dihidrokapsaisin verileri

\begin{tabular}{|c|c|c|c|c|c|c|c|c|c|c|c|c|c|}
\hline \multirow[t]{2}{*}{ İlçe } & \multirow[t]{2}{*}{ Mahalle } & \multicolumn{4}{|c|}{ Kapsaisin (ppm) } & \multicolumn{4}{|c|}{ Dihidrokapsaisin (ppm) } & \multicolumn{4}{|l|}{ Toplam (ppm) } \\
\hline & & Mak/Min & Ort & SS & $\mathrm{VK}$ & Mak/Min & Ort & SS & VK & Mak/Min & Ort & SS & $\mathrm{VK}$ \\
\hline \multirow[t]{4}{*}{ Antakya } & Demirköprü & $198.75 / 134.32$ & 2172.44 & 33.80 & 19.60 & $274.93 / 156.27$ & 7232.78 & 66.37 & 28.51 & $473.68 / 290.59$ & 405.22 & 99.90 & 24.6 \\
\hline & Apaydın & $103.69 / 77.57$ & 93.65 & 14.07 & 15.02 & $165.02 / 96.45$ & 128.51 & 34.50 & 26.85 & $264.71 / 200.14$ & 222.16 & 36.86 & 16.59 \\
\hline & Bohşin & $307.84 / 170.69$ & 9261.86 & 78.95 & 30.15 & $344.56 / 190.15$ & 5276.38 & 78.77 & 28.50 & $651.59 / 360.84$ & 538.24 & 155.60 & 28.91 \\
\hline & Avsuyu & $399.96 / 268.28$ & 8316.39 & 72.65 & 22.96 & $332.70 / 260.64$ & 4291.28 & 37.22 & 12.78 & 528.92 & 607.67 & 109.46 & 18.01 \\
\hline \multirow[t]{5}{*}{ Altınözü } & Hacıpaşa & $21.02 / 11.28$ & 17.43 & 5.35 & 30.71 & $25.14 / 17.04$ & 19.84 & 4.60 & 23.17 & $38.35 / 36.42$ & 37.27 & 0.98 & 2.64 \\
\hline & Yarseli & $335.37 / 135.99$ & 9235.21 & 99.69 & 42.38 & $189.34 / 84.58$ & 124.08 & 56.93 & 45.88 & $524.70 / 234.32$ & 359.29 & 149.36 & 41.57 \\
\hline & Yolağzı & 406.6 & 7310.02 & 85.84 & 27.69 & $432.76 / 236.87$ & 7327.79 & 98.70 & 30.11 & 479.54 & 637.80 & 183.83 & 28.82 \\
\hline & Kiyıgören & 201. & 113.67 & 86.13 & 75.78 & $302.29 / 67.83$ & 168.42 & 120.72 & 71.68 & 6.76 & 282.09 & 205.71 & 72.93 \\
\hline & Boynuyoğun & $247.10 / 66.63$ & 148.13 & 91.50 & 61.77 & $215.42 / 92.53$ & 140.93 & 65.47 & 46.45 & $462.53 / 159.16$ & 289.07 & 156.30 & 54.07 \\
\hline \multirow[t]{3}{*}{ Arsuz } & Yukarıkepirce & $108.93 / 49.75$ & 83.24 & 30.35 & 36.46 & $140.54 / 101.97$ & 7117.92 & 20.13 & 17.07 & 51.71 & 201.16 & 43.20 & 21.48 \\
\hline & $\mathrm{Ma}$ & 50.82 & 30.12 & 18.71 & 62.11 & 49.0 & 37.87 & 9.69 & 25.59 & 7.20 & 67.99 & 28.03 & 41.22 \\
\hline & Üçgüllük & $166.83 / 17.00$ & 70.24 & 83.79 & 119.30 & $337.63 / 39.74$ & 145.39 & 166.76 & 114.70 & $504.46 / 66.63$ & 215.63 & 250.18 & 116.02 \\
\hline \multirow{4}{*}{ Yayladağ } & 1Çabala & $375.24 / 16.05$ & 213.63 & 182.28 & 85.33 & $351.65 / 35.76$ & 199.06 & 158.22 & 79.48 & $726.90 / 51.80$ & 412.69 & 339.96 & 82.38 \\
\hline & Aşağıpu & 153.4 & 112.22 & 62.64 & 55.81 & 160. & 121.10 & 67.08 & 55.39 & 314.1 & 233.33 & 129.63 & 55.56 \\
\hline & & $275.76 / 83.07$ & 206.90 & 107.4 & 51.94 & 207.6 & 5167.78 & 49.45 & 29.47 & 95.52 & 374.68 & 156.34 & 41.73 \\
\hline & ğYeșilada & $593.59 / 263.26$ & 6458.61 & 173.24 & 37.78 & $568.01 / 257.07$ & 7420.85 & 156.13 & 37.10 & $1161.60 / 520.33$ & 3879.45 & 327.49 & 37.24 \\
\hline
\end{tabular}

\section{Tartışma ve Sonuç}

İncelenen popülasyonların bazı özelliklerinin ortak olduğu ve değişim göstermediği saptanmıştır. Buna göre incelenen bütün popülasyonlarda bitki büyüme modeli dik, gövde ve yapraklar tüysüz, gövde rengi yeşil, gövde şekli silindirik, yaprak rengi yeşil ve yaprak şekli ise oval olarak belirlenmiştir. Ayrıca bitkinin her koltuğundaki çiçek sayısının bir adet olduğu, taç yaprak renginin beyaz, meyve sapı ile çanak yaprağın birleştiği yerde boğum oluştuğu ve meyve sapı ile çanak yaprağın meyve üzerimde kaldığı gözlenmiş̧ir. İncelenen diğer bitki ve meyve özellikleri açısından ise popülasyonlarda varyasyon bulunduğu belirlenmiştir.

$\mathrm{Bu}$ çalışmada elde edilen bulguların bir kısmı, diğer yayınlarda bildirilen sonuçlarla uyumlu olduğu, ancak bazı bulgular bakımından ise farklılık gösterdiği belirlenmiştir. Bitki şekli, yaprak rengi, çiçek pozisyonu ve meyve tabanında boyun oluşumu bulgularımız, Çürük ve ark. (2015)'nın sonuçları ile benzerlik göstermektedir. Çalışmamızda meyve et kalınlığı bakımından popülasyonlarda ortaya çıkan varyasyon bulguları ile diğer araştırıcılar (Duman ve Düzyaman, 2004; Bozokalfa ve Eşiyok, 2010) tarafindan yayınlanan sonuçlar uyum içindedir. Ayrıca, Mutlu ve ark. (2009)'ın tohum odacık sayısı özelliği ile ilgili olarak bildirdikleri varyasyon bulgusu sonuçlarımızı desteklemektedir.

Bunlarla birlikte Çürük ve ark. (2015), inceledikleri biber genotiplerinde bitki büyüme modeli, gövde tüylülüğü, gövde rengi, meyve sapı ile çanak yaprak arasında boğum oluşumu özelliklerinde, çalışmamızdan farklı olarak varyasyon olduğunu bildirmektedirler. Çalışmamızda meyve sapı ile çanak yaprak arasında boğum oluşumu bakımından genotiplerde çeşitlilik belirlenmiş olmakla birlikte, Binbir ve Baş (2010) inceledikleri biber genotiplerinde meyve sapı ile çanak yaprak arasında boğum oluşumunun (kaliks halka oluşumu) gözlenmediğini bildirmiştir. Araştırmamızda meyve şekli bakımından varyasyon olmakla birlikte uzun meyve şeklinin çoğunlukta olduğu belirlenirken, Alan 
(1984) yaptığı çalışma sonucunda, araştırdığ1 176 farklı biber popülasyonunundan 99'unun konik meyve şekilli olduğunu bildirmiştir. Farklı araştırmalardan benzer sonuçların alınmaması, kullanılan genotiplerin farklı olması, araştırmaların değişik yükseklikte, toprak ve iklim koşullarında gerçekleştirilmiş olmasından kaynaklandığı değerlendirilmektedir.

Çalışmamızda incelenen popülasyonların çoğunda meyve uzunluğunda varyasyon tespit edilmiştir. Mutlu ve ark. (2009) ile Çürük ve ark. (2015), araştırdıkları biber genotiplerinde meyve uzunluğu açısından varyasyon tespit ettiklerini bildirmektedirler. Ancak, çalışmamızda Yeşilada popülasyonunda meyve uzunluğunda tespit edilen düşük varyasyon, bu genotipi yetiştiren çiftçilerin her yıl tohum alırken meyve uzunluğunu dikkate alarak seçim yaptıklarını işaret etmektedir.

Popülasyonların meyve rengi özellikleri bulgularına göre Kıyıgören popülasyonundan alınan meyve örneklerinde et rengi kalitesinin, genelde diğer popülasyonlardan daha yüksek olduğu belirtilebilir. Genotip, bakım koşulları ve iklim faktörlerinin kaliteyi etkilemiş olabileceği değerlendirilmektedir.

Araştırmamızda en yüksek acılığa sahip genotip olarak öne çıkan Samandă̆ Yeşilada popülasyonu meyvelerinde belirlenen ortalama kapsaisin+dihidrokapsaisin içeriği $(879.45 \mathrm{ppm}), C$. annuum çeşitlerinden olan Jalapeno ve $C$. chinense türünün Habanero çeşitlerinin bildirilen kapsaisin+dihidrokapsaisin konsantrasyonlarına (sırasıyla 1902 ve 13953 ppm, Collins ve ark., 1995) kıyasla oldukça düşük olmuştur.

Çalışma kapsamında elde edilen sonuçlardan anlaşılacağ gibi Hatay'da biber üretiminde kullanılan genotiplerin, bilhassa meyve özellikleri bakımından homojen olmadıkları görülmektedir. İncelenen özellikler dikkate alındığında Hatay biberi popülasyonları, aralarında benzerlik ve farklılık olmakla birlikte genel olarak üç gruba ayrılabileceği ortaya çıkmaktadır. Bunlar; Arsuz, AntakyaYayladağı-Altınözü ve Samandağ mahallelerinde yetiştirilen popülasyonlardır. Arsuz grubu popülasyonlarında genel olarak meyve şekli uzun, çiçek ucu şekli ağıllıklı olarak sivri, meyve az acı olarak belirlenmiştir. Antakya-Yayladağı-Altınözü grubu; meyve şekli genelde uzun olmakla birlikte konik ve tombul meyveleri bulunan, çiçek ucu şeklinin kubbe, sivri ve çukur, SÇKM içeriği diğer gruplara göre genel olarak daha yüksek ve acılığın çok düşük olduğu popülasyonlar bulunmakla birlikte Arsuz grubuna göre daha acı meyvelere sahip olan bir gruptur. Samandağ biberinde ise varyasyonun diğer gruplardan düşük, genel olarak meyve şeklinin uzun, çiçek ucu şeklinin sivri ve acılığın diğer gruplara kıyasla oldukça yüksek olduğu saptanmıştır. Ancak bu gruplamanın daha geniş popülasyonlar kullanılarak, aynı lokasyonda yürütülecek karakterizasyon çalışmaları sonucunda yapılacak moleküler analizler ve kümeleme çalışmalarıyla teyit edilmesi gerekmektedir. Zira bilindiği gibi moleküler analizler, çevre koşullarından etkilenmeyen daha güvenilir sonuçlar verebilmektedir.

\section{Teşekkür}

Çalışmamıza, 16331 nolu proje kapsamında verdiği maddi destekten dolayı Hatay Mustafa Kemal Üniversitesi Bilimsel Araştırma Projeleri Birimine teşekkür ederiz.

\section{Kaynakça}

Abbott, J.A. (1999). Quality measurement of fruits and vegetables. Postharvest Biology and Technology, $15,207-225$.

Alan, N. (1984). Collection and evaluation of pepper germplasm in Turkey. Capsicum and Eggplant Newsletter, 3, 17-18.

Anonim (1983). Genetic Resources of Capsicum. International Board For Plant Genetic Resources, Roma, $49 \mathrm{p}$.

Anonim (1995). Descriptors for Capsicum (Capsicum spp.). International Plant Genetic Resources Institute (IPGRI), Rome, $110 \mathrm{p}$.

Arpacı, B.B., Ak, A. ve Abak, K. (2016). Kök Boğazı Yanıklığı Hastalığına Dayanıklı Biber (Capsicum annuum L.) Melezlerinin Anaç Performansları. Yüzüncü Yıl Üniversitesi Tarım Bilimleri Dergisi, $26(1): 7-15$.

Aykaş, L., Taş, N., Adanacioğlu, N., Oğur, E. ve Özer, U. (2016). Ulusal tohum gen bankası. Anadolu, 26 (2), 44-50. 
Baysal, S. (2013). Üstün performansl ticari yağllk biber çeşitlerinin geliştirilmesi I. Genetik materyalin toplanması ve verim ile bazı kalite özelliklerinin belirlenmesi. Ege Üniversitesi Fen bilimleri Enstitüsü, Bahçe Bitkileri Ana Bilim Dalı, Yüksek Lisans Tezi, İzmir, $52 \mathrm{~s}$.

Binbir, S. \& Baş, T. (2010). Bazı yerel biber (Capsicum annuum L.) populasyonlarının karakterizasyonu. Anadolu, 20 (2), 70 - 88.

Bozokalfa, M.K. \& Eşiyok, D. (2010). Biber (Capsicum annuum L.) aksesyonlarında genetik çeşitliliğin agronomik özellikler ile belirlenmesi. Ege Üniv. Ziraat Fak. Derg., 47 (2), 123-134.

Collins, M.D., Wasmund, L.M. \& Bosland, P.W. (1995). Improved method for quantifying capsaicinoids in Capsicum using High-performance Liquid Chromatography. HortScience, 30(1), 137-139.

Costa, L.V., Bentes, J. LS., Lopes, M.TG., Alves, S. \& Junior, J.M.V. (2015). Morphological characterization of Amazon pepper accessions. Horticultura Brasileira, 33, 290-298.

Çürük, S., Külahlıŏlu, İ. \& Öntürk, G. (2015). Hatay'ın Yayladă̆ ilçesinde yetişstirilen yöresel biberin (Capsicum annuum L.) bitki, çiçek ve meyve özellikleri. 7. Bahçe Bitkileri Kongresi, Çanakkale, 25-29.

Duman, İ. \& Düzyaman, E. (2004). Türkiye'de yetiştirilen bazı önemli biber genotiplerinin morfolojik varyabilitesi üzerine bir araştırma. Ege ÜZF. Dergisi, 41 (3), 55-56.

FAO (Birleşmiş Milletler Dünya Tarım Örgütü). (2017). http://www.fao.org/faostat/en/\#data/QC Erişim tarihi: 30.08 .2018 .

Gökovalı, U. (2007). Coğrafi işaretler ve ekonomik etkileri: Türkiye örneği. Atatürk Üniversitesi İktisadi ve İdari Bilimler Dergisi, 21(2), 141-160.

Hancock, J.F. (1992). Plant Evolution and the Origin of Crop Species. Prentice-Hall Inc., Englewood Cliffs, New Jersey 07632, USA, $305 \mathrm{~s}$.

Heinrich, A.G., Ferraz, R.M., Ragassi, C.F. \& Reifchneider, F.JB. (2015). Characterization and evaluation of salmon-colored biquinhotype pepper progenies. Horticultura Brasileira, 33, 465-470.

İşlek, C. (2009). Serbest ve tutuklanmış Capsicum annuum L. hücre süspansiyon kültürlerinde kapsaisin üretimi üzerine bazı uyarıcıların etkisi. Ankara Üniversitesi Fen Bilimleri Enstitüsü, Biyoloji Anabilim Dalı, Doktora Tezi, Ankara, $138 \mathrm{~s}$.

Karaağaç, O. \& Balkaya, A. (2010). Bafra kırmızı biber popülasyonlarının [Capsicum annuum L. var. conoides (Mill.) Irish] tanımlanması ve mevcut varyasyonun değerlendirilmesi. Anadolu Tarım Bilim Dergisi, 25 (1), 10-20.

Karaağaç, O. \& Balkaya, A. (2017). Türkiye'de yerel sebze çeşitlerinin mevcut durumu ve islah programlarında değerlendirilmesi. TÜRKTOB Dergisi, 6 (23), 8-15.

Keleş, D. (2007). Farkll biber tiplerinin karakterizasyonu ve düşük sıcaklı̆̆a tolerans. Çukurova Üniversitesi Fen Bilimleri Enstitüsü, Doktora Tezi, Adana, $212 \mathrm{~s}$.

Keleş, D., Rastgeldi, U., Karipçin, Z., Karagül, S., Soylu, M.K., Çömlekçioğlu, N. \& Büyükalaca, S. (2016). Seleksiyon yoluyla Şanlıurfa Biber 1slahı. Alatarım Dergisi, 15 (1), 39-44.

Liu, W.Y., Kang, W.-H. \& Kang, B.-C. (2013). Basic Information on Pepper. In B.C. Kang \& C. Kole, (Eds.), Genetics, Genomics and Breeding of Peppers and Eggplants (pp. 1-15). Clemson, USA: CRC Press.

Mutlu, S., Haytaoğlu, M.A., Kır, A. \& İçer, B. (2009). Ulusal gen bankası biber (Capsicum annuum L.) materyalinde morfolojik karakterizasyon. Anadolu, 19 (1), 63-91.

Sadler, G.O. (1994). Titratable Acidity. In SS. Nielsen (Ed.), Introduction to the Chemical Analysis of Foods (pp. 81-91). Borton, USA: Jones and Bartlett Publishers.

Silva, C.Q., Jasmim, J.M., Santos, J.O., Bento, C.S., Sudre, C.P. \& Rodrigues, R. (2015). Phenotyping and selecting parents for ornamental purposes in pepper accessions. Horticultura Brasileira, 33(1), 6673.

Topaloğlu, K. (2010). Tuz stresinin chili biberlerinin pigment ve kapsaisinoid değişimi ile peroksidaz aktivitesi arasındaki ilişki. Çukurova Üniversitesi Fen Bilimleri Enstitüsü, Biyoloji Anabilim Dalı, Yüsek Lisans Tezi, Adana, 131s.

TÜIK (Türkiye İstatistik Kurumu). (2017). https://biruni.tuik.gov.tr/medas/?kn=92\&locale=tr Erişim tarihi: 30.08 .2018$.

Ulhoa, A.B, Pereira, T.NS., Ribeiro, C.SC., Moita, A.W. \& Reifschneider, F.JB. (2017). Development and morpho-agronomic characterization of Yellow Jalapeño pepper lines. Horticultura Brasileira, 35, 343-348. 